Thabiea : Journal of Natural Science Teaching
Vol. 4(1), pp. 17-32, 2021
Available online at
http://journal.iainkudus.ac.id/index.php/Thabiea
p-issn: 2580-8474, e-issn: 2655-898X

\title{
Asynchronous Learning: Its Effects on Academic Performance and Students' Motivation in Science
}

\author{
Annabeth Aque ${ }^{1 *}$, Manuel Barquilla², Amelia Buan ${ }^{3}$, Joy Bagaloyos ${ }^{4}$ \\ ${ }_{1,2,3,4}$ MSU- Iligan Institute of Technology, Tibanga, Iligan City, 9200, Philippines \\ *annabeth.aque@g.msuiit.edu.ph
}

\begin{tabular}{|c|c|}
\hline & Abstract \\
\hline $\begin{array}{l}\text { Keywords: } \\
\text { Asynchronous } \\
\text { Learning } \\
\text { Asynchronous } \\
\text { Lesson } \\
\text { Student Motivation } \\
\text { Science Learning } \\
\text { Academic } \\
\text { Performance }\end{array}$ & $\begin{array}{l}\text { The main purpose of the study is to determine the effect of asynchronous learning to } \\
\text { academic performance and students' motivation towards Science. It is necessary since } \\
\text { motivation serves as a foundation for better understanding of science concepts in an } \\
\text { asynchronous setting. The respondents are } 201 \text { grade } 11 \text { students of Iligan Computer } \\
\text { Institute (ICI) who are enrolled during the Academic Year 2020-2021. The ADDIE } \\
\text { (Analysis, Design, Development, Implementation, and Evaluation) model was used in } \\
\text { the study for the development of asynchronous lesson on Genetic Engineering with } \\
\text { Google Classroom as the online platform. The research utilized SMTSL (Students } \\
\text { Motivation Towards Science Learning) questionnaire developed by Tuan, et al. (2005) } \\
\text { composed of } 35 \text { questions encompassing six (6) domains of motivation namely, self- } \\
\text { efficacy, active learning strategies, science learning value, performance goal, } \\
\text { achievement goal and learning environment stimulation. Quantitative data together } \\
\text { with qualitative analysis showed that students are moderately motivated towards } \\
\text { science learning in an asynchronous environment. The highest identified domain is } \\
\text { science learning value indicating that students find the relevance of science with daily } \\
\text { life which makes them motivated to learn science even in a remote learning } \\
\text { environment where there is no direct contact and supervision. In contrast, self-efficacy } \\
\text { and performance goal are the least domains suggesting that students are least } \\
\text { concerned with their own ability to perform well in science learning tasks and they do } \\
\text { not compete with other students and get attention from the teacher. Using the } \\
\text { researcher-made achievement test and performance task to measure their academic } \\
\text { performance, } 80 \% \text { of the students belong to approaching proficiency, proficient and } \\
\text { advanced groups showing that students did well in science in an asynchronous learning } \\
\text { environment. Moreover, students' motivation was significantly correlated with } \\
\text { science academic performance so science academic performance can be used as } \\
\text { indirect evidence of students' motivation. Based on these findings, it is recommended } \\
\text { that curriculum experts and educators consider factors of motivation in revisiting the } \\
\text { science curriculum in an asynchronous environment. }\end{array}$ \\
\hline
\end{tabular}

To cite this article:

Aque, A., Barquilla, M., Buan, A., \& Bagaloyos, J. (2021). Asynchronous Learning: Its Effects on Academic Performance and Students' Motivation in Science. Thabiea : Journal of Natural Science Teaching, 4(1), 17-32.

\section{Introduction}

The COVID-19 pandemic has dramatically impacted the ongoing teaching-learning processes in the Philippine educational system brought on by the growth of distance education, where classes have been conducted remotely, to prevent the spread of the virus (Karalis, 2020). While distance education can be delivered via different methods such as cable TV or CD, asynchronous web-based online instruction was reported as the most adopted delivery method for distance learning (Lowenthal, Wilson, \& Parrish 2009; Moore, Dickson- 
Deane, \& Galyen, 2011; Hew et al., 2010). Asynchronous learning does not require the realtime participation of instructor and students, which can be supported through tools such as emails, discussion boards, blogs, wikis, or video/audio recordings (Parsad \& Lewis, 2008).

Empirical data revealed that motivation and interests of students in science learning are underscored as supporting conditions to the central dogma of academic performance and critical thinking in school science (Osborne \& Collins, 2001; Jegede, 2007). Accordingly, level of motivation triggers and sustains the interest of the open and distance education students when it comes to learning on their own in e-learning environments (Wighting, Liu, \& Rovai, 2008; Yukselturk \& Bulut, 2007).Thus motivation can be considered as one of the important factors which significantly contribute towards students' effective science learning (Barmby, Kind \& Jones, 2008).

However, with the new normal where learners study on their own, the situation presents a unique challenge to learner motivation since in e-learning environments most of the time, no teacher or counsellor is available to direct and encourage the student in the learning process (Liu et al., 2007). This transition to the new normal, from the four corners of the classroom to the borders of virtual reality, prompts the needs to investigate how online learning affects student motivation in providing quality education to students. Hence, this study is an effort to explore students' motivation and academic performance in science in an asynchronous online setting.

\section{Method}

A quasi-experimental design is employed in this study in order to determine the factors affecting students' motivation towards Science learning in an asynchronous environment as well as the increase in their proficiency level before and after implementation. The study is conducted in an authentic asynchronous online learning utilizing Google Classroom as the platform for learning delivery of Iligan Compute Institute (ICI), located in the province of Lanao Del Norte, Region 10. Grade 11 students of Iligan Computer Institute taking up Earth and Life Science subject who opted in online mode of learning delivery for the school year 2020-2021 constitute this study. Only 201 entries were used, representing $29 \%$ of the total number of students who opted for online modality, which is a typical survey participation rate. Some surveys did not correspond to quizzes, while some quizzes did not correspond to surveys.

The researcher employed the ADDIE (Analysis, Design, Development, Implementation, and Evaluation) model (Kurt, 2017) in developing the asynchronous lesson on Genetic Engineering creating better objective alignment, making sure to teach what to test. 


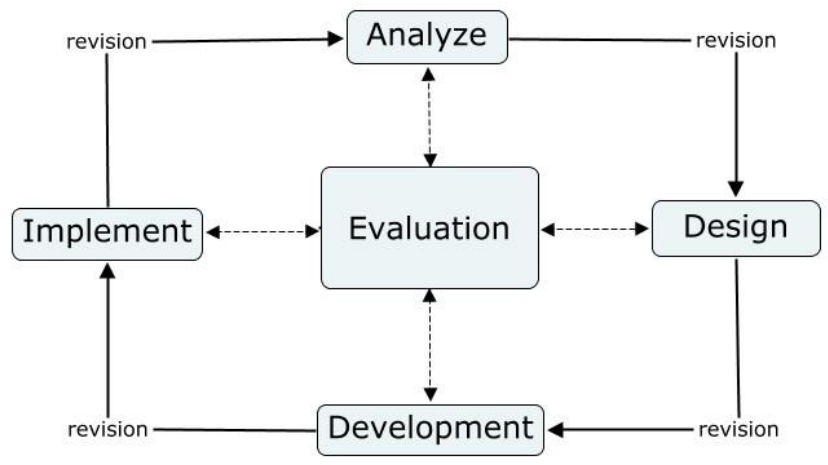

Figure 1. ADDIE Model Scheme (Kurt, 2017)

A motivation survey questionnaire, Students Motivation Toward Science Learning (SMTSL), developed by Tuan et al. (2005) was adapted and utilized to generate data for this study. This survey questionnaire consists of 35 items for the senior high school students that are distributed to the following 6 domains of motivation: (a) self-efficacy, (b) active learning strategies, (c) science learning value, (d) performance goal, (e) achievement goal, and (f) learning environment stimulation. The respondents were asked to indicate their agreement to each statement on a 5-point Likert scale. This instrument has good construct validity and also criterion-related validity (Tuan et al., 2005).

After the development of the asynchronous lesson on Genetic Engineering, it was face validated by the adviser and then evaluated by the technical expert, in-service teachers, department head and school head. Prior knowledge is gathered from the respondents. Implementation of the developed asynchronous lesson and activity followed. Posttest as well as the SMTSL survey was given to the respondents. To test the statistical significance and relationship in the achievement test and student motivation toward science learning, correlation was used. All data was statistically analyzed using SPSS Statistics 20. Qualitative analysis through clinical interview was also conducted to validate the quantitative data.

\section{Results and Discussion}

\section{Development Process of Asynchronous Lesson on Genetic Engineering}

The researcher used the ADDIE model in developing the asynchronous lesson on Genetic Engineering. This creates better objective alignment, making sure to teach what to test. The five phases: Analysis, Design, Development, Implementation, and Evaluation were followed to produce effective lessons and activities that support 21st Century learning in line with DepEd learning goals stated in DepEd Order No. 21 series of 2019.

In the Analysis Phase, the learner's profile and prior knowledge in genetic engineering were gathered. A survey was then conducted to determine the students' learning modality. From those who opted for asynchronous learning modality, 52.74\% (106 of 201 respondents) have mobile data as their internet source. This implies that they have limited access to the internet. Moreover most of the students (64.68\%), when they are online, spend their time on social networking sites such as Facebook. This could be attributed to the fact that $\mathrm{fb}$ is accessible even when in free data. Student's prior knowledge was gathered through a pre-test. 
Based on the collected data, forty percent (19 out of 48 respondents) were in the proficient level and 35\% (17 respondents out of 48) were approaching proficiency. And only 10\% (5 out of 48 respondents) were in the advanced level. Based on this result, the researcher designed and developed the video lesson that focuses on the recognized gap in the students' knowledge.

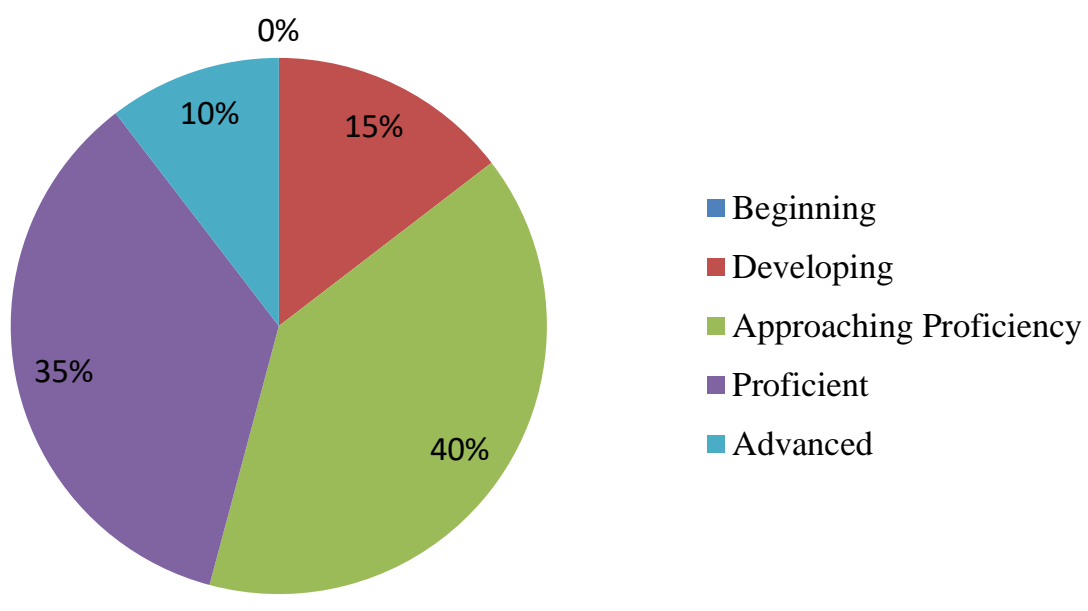

Figure 2. Students Performance in Genetic Engineering during Pre-test

The Design Phase. From the gathered information in the analysis phase of the learners' profile and performance in Genetic Engineering, the researcher designed the asynchronous lesson which is mainly the video lectures and activities. Furthermore, a performance task which integrates 21st Century Skills such as Collaboration, Knowledge Construction, Real-world Problem Solving, ICT Integration and Self-Regulation was also developed and implemented. Performance-based assessment and formative assessment is designed in a way that will measure students' ability to apply the skills and knowledge learned from a unit of study at the same time will not require face-to-face contact with others. Based on the curriculum guide and the needs of the learners in the new normal classroom environment, an asynchronous lesson is designed. Choe et. al (2019) provided guidelines for creating engaging, effective, and satisfying asynchronous lecture videos to support establishment of best practices in online instruction. The researcher used this as guiding principles in designing the asynchronous lesson. Google classroom is chosen as the online learning platform where teachers post all the learning materials including supplementary materials and activities for students to access anytime, thus the term asynchronous. This means that teachers and students don't have to be online at the same time for there will be no real-time instructions. The teacher will post the lesson in Google classroom on a weekly basis and students can sign in anytime of the week to view the materials and submit activities and take quizzes. Since half of the student population have only limited access to the internet, a repository app was developed so students could access the learning materials offline and reserve their mobile data for when they are ready to turn in activities or take quizzes. In 
addition, based on the analysis phase, students are active in social media such as Facebook. Thus, Facebook is also used as means to communicate with the students during the implementation. Teachers create fb groups that is exclusively for all the students they handle and post in there announcements and further instructions about the subject.

Table 1. Designed procedure on a weekly basis

\begin{tabular}{|c|c|c|c|}
\hline Day & Teacher & \multicolumn{2}{|c|}{ Student } \\
\hline & & Online & Offline \\
\hline 1 & $\begin{array}{c}\text { Posts Asynchronous lesson in } \\
\text { Google classroom } \\
\text { Post announcements/ } \\
\text { instructions in } \mathrm{fb}\end{array}$ & $\begin{array}{l}\text { View the lesson in } \\
\text { Google classroom }\end{array}$ & $\begin{array}{l}\text { Views lesson in the } \\
\text { repository app }\end{array}$ \\
\hline $2-5$ & $\begin{array}{c}\text { Follow up } \\
\text { Consultation time }\end{array}$ & \multicolumn{2}{|c|}{$\begin{array}{l}\text { Watch the video/s } \\
\text { reads the reading materials } \\
\text { Study the lesson } \\
\text { Conducts the authentic activity }\end{array}$} \\
\hline 6 & & $\begin{array}{c}\text { Takes quiz } \\
\text { Turn in activities in } \\
\text { Google classroom }\end{array}$ & $\begin{array}{l}\text { Submit hardcopy of answers } \\
\text { to the quiz and activity }\end{array}$ \\
\hline 7 & $\begin{array}{l}\text { Check student submission } \\
\text { Grades the activity }\end{array}$ & & \\
\hline
\end{tabular}

The Development Phase. Based on the standards and objectives, the researcher outlined and developed the asynchronous lesson on Genetic Engineering. An authentic activity is designed that would best allow learners to demonstrate what they have learned in genetic engineering considering that they will asynchronously access them. Google classroom is the online learning platform used in this study where the asynchronous lesson is administered and instructional materials are posted and accessed by the students remotely. The lessons are organized and posted on a weekly basis. Video lessons is the primary material used in the asynchronous environment to anchor and transfer learning. A PowerPoint presentation was prepared to aid the delivery of instruction in the video lecture. The PowerPoint presentation was checked by a content expert and a technical expert to make sure that it meets quality standards. A video lesson on genetic engineering which followed the Talking Head video style is recorded by one of the science teachers in ICI. Supplementary materials about the lesson such as video clips from YouTube and other reading sources were also prepared to support learning. Performance-based assessment and formative assessment were also developed and posted to measure students' ability to apply the skills and knowledge learned from a unit of study. 


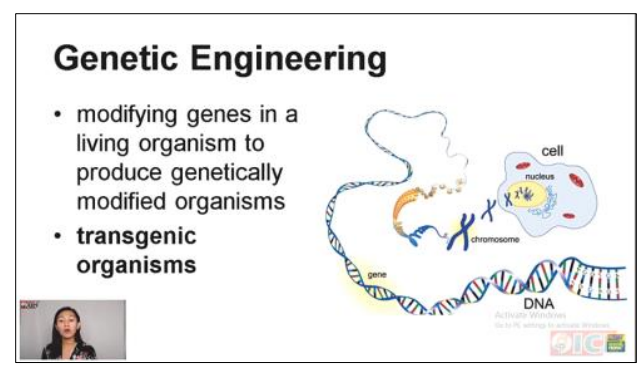

Figure 3. Screenshot of the developed asynchronous video lesson

During the Implementation Phase, the teacher-researcher ensures that the learning materials including the video lesson, activity and supplementary materials were all posted in the Google classroom. To measure students' ability to apply the skills and knowledge learned from the lesson on Genetic Engineering, a performance task in a form of an authentic activity with 21 st century skills integration was developed. The students evaluated the benefits and risks of using GMOs by taking a particular stand on the matter through a campaign video advertisement where the also presented evidences on why they took the particular standpoint on GMOs. This activity was done by groups of approximately 10 students where collaboration was done asynchronously through a group chat they created in Facebook messenger to diminish face-to-face interaction. They were instructed to record clips of their part individually and consolidate it through editing. The video output was turned in the Google classroom and were graded. This was completed in more than one week. The teacherresearcher made sure that the students are given the ability to learn and explore on their own at their own pacing. The performance task, which is a group activity with ICT integration, ensures learner participation in the learning process.

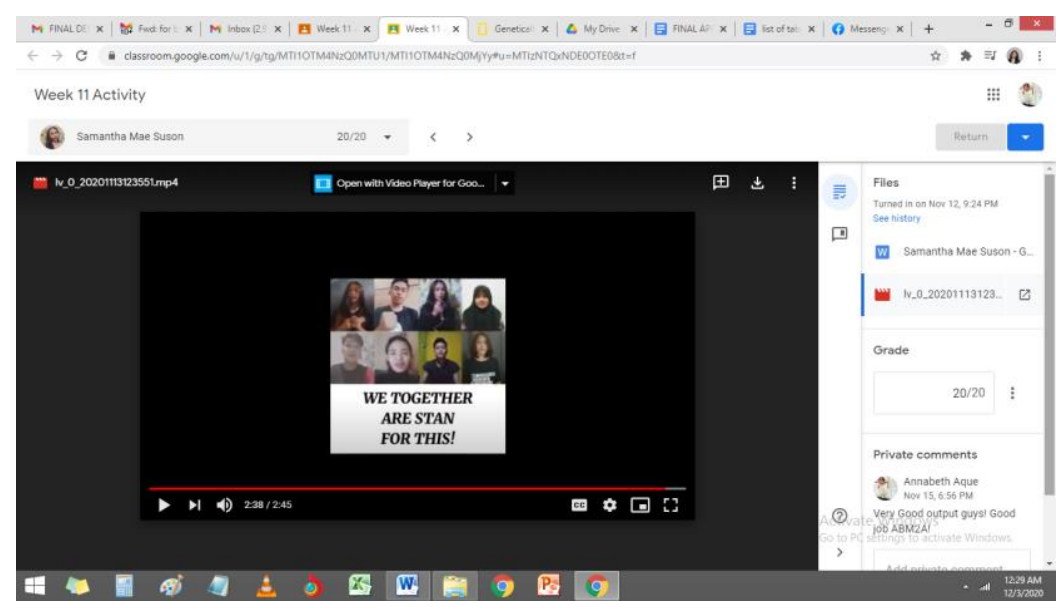

Figure 4. Sample video outputs of the students

The Evaluation Phase measures the effectiveness of the instruction and developed activities. This actually occurs throughout the entire instructional design phases- within phases, between phases, and after implementation. Pre-test and post-test were conducted and compared to assess the overall effectiveness of the instruction. Formative assessment was also conducted by the teacher-researcher during the learning process in order to modify teaching and learning activities to improve student achievement and performance. Content evaluators 
helped with the improvement of the designed performance task using the $21^{\text {st }}$ CLD. The developed activity gained an excellent rating in promoting $21^{\text {st }}$ century skills by the panels after a series of revision. Moreover a panel of evaluators helped in ensuring the quality of the instructional video material. An Instructional Video Evaluation instrument was adopted in evaluating the video lesson using a 5-point Likert scale where 1 is poor and 5 is excellent. Over-all, the final video lesson acquired a very good rating from the evaluators after applying previous comments such as improving on the slides used and shortening the length of the video.

\section{Students' Level of Motivation in Science Learning in an Asynchronous Learning Setting}

Students' motivation towards Science learning was estimated based on the means of their scores for each subscale and for the whole questionnaire. Cavaş's (2011) classification system according to which a high level of motivation included means between 4.41 and 5.00, a moderate level of motivation included means between 4.40 and 3.39 and a low level of motivation included means lower than 3.38 is followed.

Table 2. Students' motivation towards Science learning in an asynchronous environment

\begin{tabular}{lccc}
\hline & Mean & Interpretation & Rank \\
\hline SMTSL & $\mathbf{3 . 4 0 5}$ & Moderate & \\
\hline Self-Efficacy & 2.677 & Low & 5 \\
\hline Active Learning Strategies & 3.834 & Moderate & 3 \\
\hline Science Learning Value & 3.925 & Moderate & 1 \\
\hline Performance Goal & 2.295 & Low & 6 \\
\hline Achievement Goal & 3.860 & Moderate & 2 \\
\hline Learning Environment Stimulation & 3.613 & Moderate & 4 \\
\hline
\end{tabular}

Based on the data (shown in Table 2) students are moderately motivated (mean = 3.405) towards science learning in an asynchronous learning environment. Additionally, students are moderately motivated in active learning strategies, science learning value, achievement goal, and learning environment stimulation. The highest identified domain is science learning value with a mean of 3.925 followed by achievement goal and active learning strategies with 3.860 and 3.834 mean values, respectively. Having science learning value as first rank signifies that students acquire problem-solving competency, experience the inquiry activity, stimulate their own thinking, and find the relevance of science with daily life. If they can perceive these important values, they will be motivated to learn science even in a remote learning environment where there is no direct contact and supervision. On the other hand, results shown that self-efficacy and performance goal are the least domains indicating that students are least concerned with their own ability to perform well in science learning tasks and they do not compete with other students and get attention from the teacher.

Previous studies demonstrate that if the students' goal towards tasks is for performance, they will be concerned more with performing better than their peers and impressing their teachers (Brophy 1998; Pintrich \& Schunk 1996). However in the present study, where there is no real time instruction between students and teachers, students could not compete directly with their peers and impress their teachers. The lack of face-to-face interaction between students and their peers in the asynchronous learning environment could 
have contributed to the students' low motivation in terms of performance goal.

\section{Academic performance level of the students based on their achievement test and performance task}

Under DepEd Order No. 31, learners are now graded in the core subjects based on Written Works (40\%) and Performance Task (60\%). Five levels of proficiency were also identified, namely: Beginning, Developing, Approaching Proficiency, Proficient, and Advanced. The Beginning (B) level will be given to students with numerical grades of 74 percent and below; Developing (D) level for those with grades of 75 to 79 percent; Approaching Proficiency (AP) for those with grades 80 to 84 percent; Proficient (P) for those with grades 85 to 89 percent; and Advanced (A) for those with 90 percent and higher.

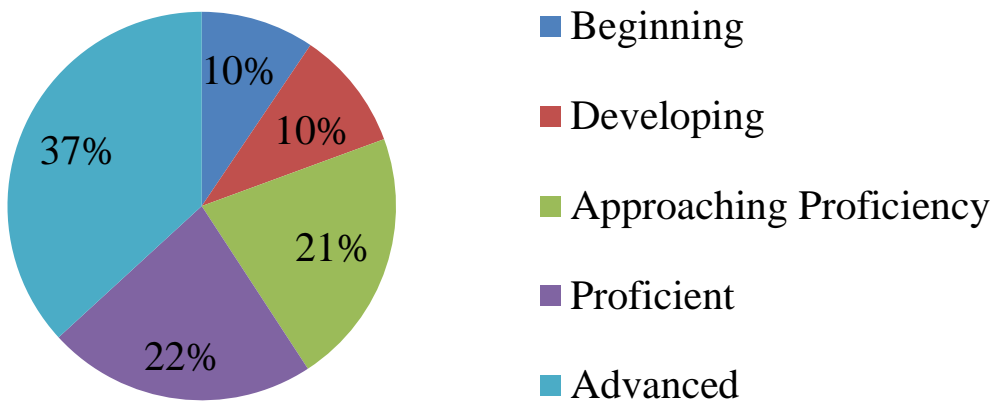

Figure 5. Student levels of academic performance

Based on the computation of their achievement test and performance task, results shows (Figure 5) that $80 \%$ of the students belong to approaching proficiency $(21 \%$ or $43 / 201)$, proficient $(22 \%$ or $45 / 201)$ and advanced (37\% or $74 / 201)$ groups. This shows that students did well in their academic performance in science in an asynchronous learning environment.

\section{Students' Motivation in Science Learning and Their Academic Performance}

Additionally, relationship between students' motivation in Science learning and their academic performance was investigated using Pearson correlation analysis of the SMTSL questionnaire with science achievement (Table 3). The SMTSL questionnaire has significant correlation with students' science academic performance $(r=0.178, p<0.05)$. Except for self-efficacy and performance goal, the other four scales have significant correlation with students' academic performance in science $(\mathrm{p}<0.01, \mathrm{p}<0.05)$. 
Table 3. Pearson correlation analysis of the SMTSL questionnaire with science achievement

\begin{tabular}{|c|c|c|c|c|c|c|c|}
\hline $\begin{array}{c}\text { Pearson } \\
\text { correlation } \\
\text { (significan } \\
\text { ce } \\
\text { two-tailed) }\end{array}$ & $\begin{array}{c}\text { SMTS } \\
\text { L }\end{array}$ & $\begin{array}{c}\text { Self- } \\
\text { efficac } \\
y \\
\end{array}$ & $\begin{array}{c}\text { Active } \\
\text { learnin } \\
\text { g } \\
\text { strategi } \\
\text { es } \\
\end{array}$ & $\begin{array}{c}\text { Science } \\
\text { Learni } \\
\text { ng } \\
\text { Value } \\
\end{array}$ & $\begin{array}{c}\text { Performan } \\
\text { ce goal }\end{array}$ & $\begin{array}{c}\text { Achieveme } \\
\text { nt goal }\end{array}$ & $\begin{array}{c}\text { learning } \\
\text { environme } \\
\text { nt } \\
\text { stimulatio } \\
n \\
\end{array}$ \\
\hline $\begin{array}{c}\text { Science } \\
\text { Academic } \\
\text { Performan } \\
\text { ce } \\
\end{array}$ & $.178 *$ & .005 & $.203 *$ & .092 & .033 & $.192 * *$ & $.159 *$ \\
\hline
\end{tabular}

Notice the highest correlation is 0.203 between active learning strategies and academic performance. This correlation is significant at $\mathrm{p}<0.05$. Despite being significant, it is important to remember this correlation is weak.

The fact that students' motivation was significantly correlated with science academic performance indicates the stability of motivation in relation to students' academic performance. Thus, science achievement is often used as indirect evidence of students' motivation (Pintrich \& Schunk 1996). The SMTSL questionnaire has proven that motivation has a significant correlation with cognition as mentioned by several researchers (Haladyna \& Shaughnessy 1982, Napier \& Riley 1985, Simpson \& Troost 1982, Thompson \& Mintzes 2002).

\section{Factors affecting student motivation in Science learning}

Factors addressed in the scope of the study were self-efficacy, performance goal, active learning strategies, task learning value, achievement goal, and learning environment stimulation. In-depth study in the domains of motivation that affects the students in an asynchronous environment is expounded below. However due to time constraints, only the highest (science learning value) and lowest (performance goal) factors were probed in this study through a clinical interview for the purpose of supporting the quantitative data.

Table 4 summarizes the factors affecting students' motivation towards Science learning in an asynchronous environment according to their level of academic proficiency. Results show that students in the advanced and proficient levels are moderately motivated with mean values of 3.512 and 3.468 respectively whereas those in the approaching proficiency, developing and beginning levels are with low motivation with mean values of $3.348,3.269$ and 3.110 correspondingly. In a follow-up interview those with low motivation explains that factors such as their classmates' cooperation in class activities affects their motivation. "Some of my classmates do not respond to our group chat and others rely solely on some to work on our task" a student said (Student A, phone interview, January 12, 2021, 2:15PM). Still a student added "because there's so much to do, I tend to focus only on the task and not on the learning anymore"; the environment also affected students' motivation "I become lazy sometimes because our place is an open space and the noise in the surroundings get in", she added (Student E, phone interview, January 12, 2021, 3:15PM). 
Table 4. Factors affecting students' level of motivation according to level of academic proficiency

\begin{tabular}{|c|c|c|c|c|c|c|c|c|}
\hline $\begin{array}{l}\text { Academic } \\
\text { Proficien } \\
\text { cy }\end{array}$ & $\begin{array}{l}\text { Self- } \\
\text { Effic } \\
\text { acy }\end{array}$ & $\begin{array}{c}\text { Active } \\
\text { Learning } \\
\text { Strategies }\end{array}$ & $\begin{array}{c}\text { Science } \\
\text { Learning } \\
\text { Value }\end{array}$ & $\begin{array}{l}\text { Perfor } \\
\text { mance } \\
\text { Goal }\end{array}$ & $\begin{array}{c}\text { Achiev } \\
\text { ement } \\
\text { Goal }\end{array}$ & $\begin{array}{c}\text { Learning } \\
\text { Environment } \\
\text { Stimulation }\end{array}$ & $\begin{array}{c}\text { SMT } \\
\text { SL }\end{array}$ & $\begin{array}{l}\text { Inter } \\
\text { preta } \\
\text { tion }\end{array}$ \\
\hline $\begin{array}{l}\text { Advanced } \\
(n=74)\end{array}$ & $\begin{array}{c}2.68 \\
7 \\
\end{array}$ & 3.973 & 4.124 & 2.260 & 4.046 & 3.736 & 3.512 & $\begin{array}{c}\text { Mode } \\
\text { rate }\end{array}$ \\
\hline $\begin{array}{l}\text { Proficient } \\
(n=45)\end{array}$ & $\begin{array}{c}2.76 \\
8 \\
\end{array}$ & 3.950 & 3.920 & 2.356 & 3.862 & 3.678 & 3.468 & $\begin{array}{c}\text { Mode } \\
\text { rate }\end{array}$ \\
\hline $\begin{array}{l}\text { Approach } \\
\text { ing } \\
\text { Proficien } \\
\text { cy } \\
(n=43)\end{array}$ & $\begin{array}{c}2.66 \\
4\end{array}$ & 3.762 & 3.823 & 2.419 & 3.786 & 3.450 & 3.348 & Low \\
\hline $\begin{array}{l}\text { Developin } \\
\mathrm{g} \\
(n=21)\end{array}$ & $\begin{array}{c}2.61 \\
9\end{array}$ & 3.661 & 3.781 & 2.012 & 3.752 & 3.516 & 3.269 & Low \\
\hline $\begin{array}{l}\text { Beginnin } \\
\mathrm{g} \\
(n=18)\end{array}$ & $\begin{array}{c}2.50 \\
0\end{array}$ & 3.347 & 3.533 & 2.319 & 3.389 & 3.444 & 3.110 & Low \\
\hline Mean & $\begin{array}{c}2.64 \\
8 \\
\end{array}$ & 3.739 & 3.836 & 2.273 & 3.767 & 3.565 & & \\
\hline $\begin{array}{l}\text { Interpret } \\
\text { ation }\end{array}$ & Low & Moderate & Moderate & Low & $\begin{array}{c}\text { Moder } \\
\text { ate }\end{array}$ & Moderate & & \\
\hline
\end{tabular}

Furthermore, science learning value is the highest factor affecting students' motivation towards science learning in an asynchronous environment. Students agree that, I think that learning science is important because I can use it in my daily life; I think that learning science is important because it stimulates my thinking; In science, I think that it is important to learn to solve problems; In science, I think it is important to participate in inquiry activities and It is important to have the opportunity to satisfy my own curiosity when learning science. Science learning stimulates students' own thinking making them curious about things and finds the relevance of science with daily life. Further analysis of data based on clinical interview supports the contention of the quantitative data as described by students:

"Science makes me question things and stimulates my curiosity making me eager to learn about it". The value of science learning is to let students find the relevance of science with daily life, "I can relate the things I learned in Science in my day-to-day activities" (Student A, phone interview, January 12, 2021, 2:00PM); and "[Science] learning is really important to us so we can understand and explain to others about the important happenings in our surroundings" another student explained (Student B, phone interview, January 12, 2021, 2:15PM).

Since students perceive these important values, they are moderately motivated to learn science even in an asynchronous setting. These findings suggest that in order to increase students' motivation toward science learning in an asynchronous curriculum it is important to give weight on contextualizing the lessons to make it relevant to the students (Wyatt, T., 2014). 
On the other hand performance goal is the least motivating factor affecting students' motivation towards science learning in an asynchronous setting which is attributed to the fact that students see less of their teachers and classmates making it difficult to compete. Students disagree that, I participate in science courses to get a good grade; I participate in science courses to perform better than other students; I participate in science courses so that others students think that I'm smart and I participate in science courses so that the teacher pays attention to me. Further investigation of data based on clinical interview validates the assertion of the quantitative data as described by students:

"I study science not to show off" (Student A, B, C, D and E, phone interview, January 12, 2021, 2:15PM); "I also get wrong sometimes so it's better for us to help each other rather than compete and make things complicated and problematic instead" (Student C, phone interview, January 12, 2021, 2:30PM); and "I don't study science just for the sake of grades. I study science to learn new things I wouldn't learn in other place. And I don't really compete with anyone nor seek attention to be recognized by the teacher. I just simply want to learn new things" (Student D, phone interview, January 12, 2021, 2:45PM).

This lack of desire for competition explains students' low level of motivation in terms of performance goal. To compete with other students and get attention from the teacher are the least that motivates student's goals in science learning. According to Lai, E.R. (2011) collaboration can have powerful effects on student learning, particularly for low-achieving students. Thus activities that promote collaboration and cooperation will better benefit students in an asynchronous environment. Teachers should structure tasks in ways that will support the goals of collaboration, specify "ground rules" for interaction, and regulate such interactions (Lai, E. R., 2011).

\section{Conclusion}

The developed asynchronous lesson on genetic engineering could be used as reference by educators as an effective learning tool in the transfer of learning in the new normal setting. In a remote learning environment where there is no direct contact and supervision, a number of factors especially in self-efficacy and performance goal could be explored and studied further to increase student motivation toward science learning in an asynchronous setting. It is recommended that schools and educators consider factors of motivation in implementing science in an asynchronous setting. Assessing motivational levels of students will help educational institutions and science instructors to find the solution for the problems regarding student's motivation that will help provide a better environment for learning. Moreover in designing the curriculum for the asynchronous classroom, it is recommended that based on the results on self-efficacy tasks must be designed in such a way that instructions are clearly stated so students feel that they can do it even on their own (self-supported) to develop their confidence in their own ability to perform well in science learning tasks. Also, performance goal is the least motivating factor affecting students' motivation towards science learning in an asynchronous setting. To anchor this result it is recommended that in curriculum design more collaborative activities be given so students will be encouraged to participate and cooperate rather than compete for grades or for the attention of the teacher which is an unlikely occurrence in an asynchronous classroom. Lastly, it is recommended that more 
parent orientation be conducted to discuss further what could be done in the homes to raise student motivation in the learning environment. Finally, this study is limited to a limited sample size due to the pandemic. It is then recommended that further researches related in assessment of motivation of students towards Science learning in an asynchronous environment be conducted extensively to allow a wide range of data for more in-depth analysis.

\section{Acknowledgment}

Sincere gratitude to Iligan Computer Institute (ICI) administration for allowing this study to be conducted to its senior high school students and for the use of the school's facilities for the implementation of this research.

\section{References}

Atkinson, J.W., \& Birch, D. (1978). An Introduction to Motivation (2nd ed.). New York: Van Nostrand.

Ayub, N.,"Effect of intrinsic and extrinsic motivation on academic performance,"Pakistan Business Review, 363-372 (2010, July)

Bandura, A. (1981). Self-referent thought: A developmental analysis of self-efficacy. In J.H. Flavell and L. Ross (Eds) Social Cognitive Development: Frontiers and Possible Futures. New York: Cambridge University Press.

Bandura, A. (1982). Self-efficacy mechanism in human agency. American Psychologist, 37, $122-147$.

Bandura, A. (1997). Self-efficacy: The exercise of control. New York: W.H. Freeman.

Barlia, L., \& Beeth, M.E. (1999). High school students' motivation to engage in conceptual change learning in science. Paper presented at the annual meeting of the National Association for Research in Science Teaching, Boston, MA, March.

Barmby, P., Kind, P.M., \& Jones, K. (2008). Examining changing attitudes in secondary school science. International Journal of Science Education, 30(8), 1075-1093. http://dx.doi.org/10.1080/09500690701344966

Brophy, J. (1998). Motivating students to learn. Madison, WI: McGraw Hill.

Brophy, Jere E. (2010). Motivating students to learn. New York, NY: Routledge.

Choe, R. C., Scuric, Z., Eshkol, E., Cruser, S., Arndt, A., Cox, R., \& Crosbie, R. H. (2019). Student Satisfaction and Learning Outcomes in Asynchronous Online Lecture Videos. CBE—Life Sciences Education, 18(4), ar55. doi:10.1187/cbe.18-08-0171

Deci, E., \& Ryan, R. (1991). A motivational approach to self: Integration in personality. In R.

Duffy, T. M. \& Kirkley, J. R. (2004). Learning theory and pedagogy applied in distance learning: The case of Cardean University. In T. M. Duffy, \& J. R. Kirkley, (Eds), Learner-Centered Theory and Practice in Distance Education (pp. 107 - 141). Mahwah, New Jersey: Lawrence Erlbaum Associates Publishers. 
Elliot, A.J. \&Dweck, C.S. (Eds.),Handbook of competence and motivation. New York: Guilford Press(2005)

Erb, M. (1996). Increasing students' responsibility for their learning through multiple intelligence activities and cooperative learning. Unpublished master's thesis, Saint Xavier University, IL.

Fırat M, Kılınç H, \& Yüzer TV. Level of intrinsic motivation of distance education students in e-learning environments. Journal of Computer Assisted Learning. 2018;34:63-70. https://doi.org/10.1111/jcal.12214

Garcia, T., \& Pintrich, P. R. (1994). Regulating motivation and cognition in the classroom: The role of selfschemas and self-regulatory strategies. Self-regulation of learning and performance: Issues and educational applications, 127-153.

Garcia, T., \& Pintrich, P.R. (1992). Critical thinking and its relationship to motivation, learning strategies, and classroom experience. Paper presented at the Annual Meeting of the American Psychological Association, Washington, DC, August.

Huang, S.Y., \& Waxman, H.C. (1995). Motivation and learning environment differences between Asian-American and white middle school students in mathematics. Journal of Research and Development in Education, 28(4), 208-219.

Jegede, S.A. (2007). Students' anxiety towards the learning of chemistry in some Nigerian secondary schools. Educational Research and Review, 2(7), 193-197.

Karalis, T. (2020). Planning and Evaluation during Educational Disruption: Lessons Learned from COVID 19 Pandemic for Treatment and Emergencies in Education. European Journal of Education Studies, 7(4). https://doi.org/10.5281/zenodo.3789022

Kurt, S. "ADDIE Model: Instructional Design," in Educational Technology, August 29, 2017. Retrieved from https://educationaltechnology.net/the-addie-model-instructionaldesign/

Kuyper, H., van der Werf, M.P.C., \& Lubbers, M.J. (2000). Motivation, meta-cognition and self-regulation as predictors of long term educational attainment. Educational Research and Evaluation, 6(3), 181-201.

Lai, E. R. (2011). Critical Thinking: A Literature Review Research Report. London: Parsons Publishing.

Lee, O. (1989). Motivation to learning science in middle school classrooms. University Microfilms International. Unpublished doctoral dissertation, Michigan State University, East Lansing.

Lee, O., \& Brophy, J. (1996). Motivational patterns observed in sixth-grade science classrooms. Journal of Research in Science Teaching, 33(3), 585-610.

Liu, Jianguo \& Dietz, Thomas \& Carpenter, Stephen \& Alberti, Marina \& Folke, Carl \& Moran, Emilio \& Pell, Alice \& Deadman, Peter \& Kratz, Timothy \& Lubchenco, Jane \& Ostrom, Elinor \& Ouyang, Zhiyun \& Provencher, William \& Redman, Charles \& Schneider, Stephen \& Taylor, William. (2007). Complexity of Coupled Human and Natural Systems. Science (New York, N.Y.). 317. 1513-6. 10.1126/science.1144004. 
Lowenthal, P. R., \& Dunlap, J. (2011). Investigating students' perceptions of various instructional strategies to establish social presence. Paper presented at the annual meeting of the American Educational Research Association, New Orleans, LA.

Matuga, J.M.,"Self-regulation, goal orientation and academic achievement of secondary students in online university courses,"Educational Technology \& Society, 12(3): 411(2009)

McCombs, B. L. (2001). Self-regulated learning and academic achievement: A phenomenological view. In B. J.

Mulig-Cruz, C., Barquilla, M., Tabudlong, J., \& Magallanes, J. Development of Progressive Learning Theory - Based Physics Enhancement Course (May 25, 2015). Proceedings Journal of Education, Psychology and Social Science Research, 2015 , Available at SSRN: https://ssrn.com/abstract=3100196

National Research Council (1996). National Science Education Standards. Washington, DC: National Academy Press.

Niemiec, C. P., \& Ryan, R. M. (2009). Autonomy, competence, and relatedness in the classroom. School Field, 7(2), 133-144. doi:10.1177/1477878509104318

Nolen, S.B., \& Haladyna, T.M. (1989). Psyching out the science teacher: Students' motivation, perceived teacher goals and study strategies. Paper presented at the annual meeting of the American Educational Research Association, San Francisco, CA, March.

Ominowa OT, Bamidele EF. Effectiveness of video-mediated instruction on teaching secondary school practical chemistry in Akure South Local Government Area of Ondo State, Nigeria. European Journal of Education Studies. 2016;2(5).

Osborne, J.F., \& Collins, S. (2001). Pupils' views of the role and value of the science curriculum: A focus-group study. International Journal of Science Education, 23(5), 441-468. http://dx.doi.org/10.1080/09500690010006518

Pajares, F. (1996). Self-efficacy beliefs in academic settings. Review of Educational Research, 66, 543-578.

Patric, A.O., Kpangban, E.\&Chibueze, O.O.,"Motivation effects on test scores of senior secondary school science students,"Studies on Home and Community Science, 1(1): 57-64. (2007)

Patrick, H., Mantzicopoulos, P., Samarapungavan, A.\& French, B. F.,"Patterns of young children"s motivation for science and teacher-child relationships,"The Journal of Experimental Education, 76(2): 121-144 (2008)

Peipei, L.\&Guirong P.,The Relationship between motivation and achievement(2009)

Pintrich, P. R. (2000). Multiple goals, multiple pathways: The role of goal orientation in learning and achievement. Journal of Educational Psychology, 92(3), 544-555.

Pintrich, P. R., \& De Groot, E. V. (1990). Motivational and self-regulated learning components of classroom academic performance. Journal of educational psychology, 82(1), 33-40. 
Pintrich, P. R., Smith, D. A. F., Garcia, T., \& McKeachie, W. J. (1991). A manual for the use of the Motivated Strategies for Learning Questionnaire (MSLQ). Ann Arbor. Michigan. American Association for the Advancement of Science (1993). Benchmarks for Science Literacy. New York: Oxford University Press.

Pintrich, P.R., Marx, R.W., \& Boyle, R.A. (1993). Beyond cold conceptual change: The role of motivational beliefs and classroom contextual factors in the process of conceptual change. Review of Educational Research, 63(2), 167-199.

Spandana B., Neela Rani R. \& Suchiritha Devi S., "Students' Motivation towards Science Learning (SMTSL) - An Intervention with Video and Quizzes" Current Journal of Applied Science and Technology, 39(4): 85-91 (2020)

Stein, D. S., Wanstreet, C. E., Calvin, J., Overtoom, C., \& Wheaton, J. E. (2005). Bridging the transactional distance gap in online learning environments. American Journal of Distance Education, 19(2), 105-118. doi:10.1207/s15389286ajde1902_4

Strike, K.A., \& Posner, P.J. (1983). On rationality and learning: A reply to West and Pines. Science Education, 67, 41-43.

Strike, K.A., \& Posner, P.J. (1992). A revisionist theory of conceptual change. In R.A. Duschl and R.J. Hamilton (Eds) Philosophy of Science, Cognitive Psychology, and Educational Theory and Practise (pp. 147-176). Albany, NY: State University of New York Press.

Talib, O., Luan, W.S., Azhar, S.C.\&Abdullah, N.,"Uncovering Malaysian studentse motivation to learning science,"European Journal of Social Sciences, 8(2): 266-276. (2009)

Taylor, A. (2007). Programming for the internet and experiential learning: A new approach incorporating a constructed world. International Journal of Technology \& Design Education, 17(2), 217-229.

Tella, A.,"The impact of motivation on student"s academic achievement and learning outcomes in mathematics among secondary school students in Nigeria,"Eurasia Journal of Mathematics, Science \& Technology Education, 3(2): 149-156(2007)

Tuan, H.L, Chin. C.C, and Shieh, S.H. (2005). The development of a questionnaire to measure students' motivation towards science learning. International Journal of Science Education, 27(6), 639-654.

Tuan, H.L., \& Chin, C.C. (2000). Promoting junior high school students' motivation toward physical science learning (III). Report for Taiwan National Research Council (NSC 89-2511- S018-030).

Uguroglu, M.E., Schiller, D.P., \& Walberg, H.J. (1981). A multidimensional motivational instrument. Psychology in the Schools, 18, 279-285.

Urdan, T.C., \& Maehr, M.L. (1995). Beyond a two-goal theory of motivation and achievement: A case for social goals. Review of Educational Research, 65(3), 213243. 
Von Glasersfeld, E. (1998). Cognition, construction of knowledge and teaching. In M.R. Matthews (Ed.) Constructivism in Science Education (11-30). Dordrecht: Kluwer Academic.

West, L.H.T., \& Pines, A.L. (1983). How 'rational' is rationality? Science Education, 67, 3739.

Wu, S.J., \& Tuan, H.L. (2000). A case study of students' motivation in a ninth grader physical science class. In D. Fisher and J.H. Yang (Eds) Proceedings of the Second Conference on Science, Mathematics and Technology Education (341-350). Perth: Curtin University of Technology.

Wyatt, Tasha. (2014). Understanding the Process of Contextualization. Multicultural Teaching and Learning. 10. 111-132. 10.1515/mlt-2013-0026.

Yong, B. C. S.,"Form 5 science students"e attitudes and achievement in biology: gender differences. In H.S. Dhindsa, S.B. Lim, P. Achleitner\& M.A. (Ken) Clements (Eds.),"Studies in Science, Mathematics and Technical Education, University Brunei Darussalam, 45-51 (2003) 